\title{
Audit Committee Effectiveness and Earnings Management Among Publicly Listed Firms in Kenya
}

\author{
Collins Kapkiyai ${ }^{1 *}$, Josephat Cheboi ${ }^{2}$, Joyce Komen ${ }^{3}$ \\ 1, 2 Department of Accounting and Finance, Moi University, Kenya \\ 3 Department of Management Science, Moi University, Kenya \\ *Corresponding author: collokapkiai@gmail.com
}

\begin{abstract}
Article History
Received 2020-01-23

Revised 2020-02-24

Accepted 2020-02-26

Published 2020-02-28
\end{abstract}

\section{Keywords}

Earnings Management

Audit Committee Effectiveness Audit

Committee Independence

Audit Committee Meeting frequency

Audit Committee Financial Expertise

\section{How to cite?}

Kapkizyai, C., Cheboi, J., \& Komen, J. (2020). Audit Committee Effectiveness and Earnings Management Among

Publicly Listed Firms in Kenya.

SEISENSE Journal of Management, 3(2), 31-44. doi:

10.33215/sjom.v3i2.292
Abstract

Objective: The paper sought to investigate the role of an effective audit committee in controlling earnings management practices.

Design / Methodology: A panel data sourced from the audited financial reports of firms listed at the Kenyan Nairobi Securities Exchange for the periods between 2004 and 2017 were analyzed using a panel regression model.

Findings: Audit committee effectiveness proved an important monitoring mechanism for earnings management. The independence, Meeting frequency, and financial expertise of the audit committee evidenced a negative and significant effect on earnings management.

Practical Implications: Firms need to ensure that their audit committees operate effectively. This is achieved through enhancing their independence, ensuring optimal meeting frequency, and a higher number of members with financial expertise for fewer earnings management.

Originality: The paper suggests the ways through which audit committee effectiveness can be enhanced to reduce earnings management amid rampant global financial scandals. 


\section{Introduction}

Earnings are the most important accounting items in generating and interpreting financial reports. They are key components in determining decisions on dividends and investment; measures of firm performance provides a criterion for valuing stocks and are the basis for financial forecasting (Mohammady, 2010). Its significance justifies the recent global scholarly attention towards earnings and earnings management, especially owing to its implication on a myriad of stakeholders. Earnings management in the modern business environment has been of great concern due to its explanatory power towards the evident global financial frauds.

At the end of every financial period, reporting on earnings is expected of every listed firm, whereby it is made based on the prescribed practices and procedures set by the accounting standards-setting bodies. However, these standards provide an opportunity for managers to exercise their discretion in financial reporting, such as the choice of assets impairment methods, depreciation approach, revenue recognition methods, and recording of receivables. Given the discretion to make accounting choices, opportunistic managers get involved in discretionary earnings management when preparing and presenting financial statements to achieve their purposes (Z. Lin, Liu, \& Noronha, 2016). According to (Healy \& Wahlen, 1999), earnings management is the use of judgment in financial reporting and in structuring transactions to alter financial reports to either mislead some stakeholders about the underlying economic performance of the company or to influence contractual outcomes that depend on reported accounting numbers.

Financial analysts, regulators, and accounting experts have been increasingly concerned about the probity of financial statements, mainly after a sequence of high-profile accounting scandals and inconspicuous fraud companies (Singh, Aggarwal, \& Anand, 2016). Management engages in opportunistic accruals management to achieve their benefits such as pay-for-performance incentives for retention purposes and to portray a good image shortly before retirement. Cornett, McNutt, and Tehranian (2009) added that earnings management is conducted through window dressing up of financial statements shortly before the offering of public securities to enhance the top management's financial benefits and job security, to evade infringement of lending agreements and to cut the cost of regulation or to increase its benefits.

Managers are more likely to make decisions that diverge from the shareholders' interests in a business environment where there is a lack of effective control procedures and thus, resulting in managers abusing their discretion over earnings, by engaging in earnings management. This generates the necessity to incur monitoring costs borne by the shareholders. Due to the conflict of interest between the management and the shareholders, the incentive for misrepresentation of company results emanates (Albu \& Girbina, 2015), therefore resulting in agency conflicts. This act of discretionary earnings manipulation results into agency conflicts between the company shareholders and the top management who are the agents, since the owners are misled on the true value of their investments. Earnings management is more likely to be detrimental to the firm as it minimizes the credibility of disclosed earnings and its utility in investment decisions. This hurts reducing investor confidence in the financial reports.

There exists an agency relationship between the shareholders and the management, and an agency conflict arises almost inevitably caused by the division of ownership and control, especially in the current business environment where the two roles are distinct. Due to these separations of roles, the executives are placed in an advantaged position that allows them all the freedom to make decisions that could either align with or entrench the company's goal of maximizing the shareholder value (Hassan \& Ahmed, 2012). Supreme control and management of the company's resources by the managers also give them an upper hand, which may result in enabling them to make decisions that resonate with their individual goals, contrary to those of their employers who are the shareholders (NAZIR \& AFZA, 2018). 
To work on the agency conflicts amongst the management and the shareholders, agency theory suggests a monitoring mechanism to be put in place like a control mechanism towards constraining this opportunistic behavior of the management. To curb any deviation of collective interest and to ensure adequate accountability of resources, a firm needs a robust monitoring structure which promotes efficient output and ethical behavior, since ensuring minimal misstatements on the reported financial accounts goes a long way in reducing the divergence of interests. Sound financial reporting eliminates the agency issues by filling in the information asymmetry gap that is evident between the management and the owners (Karamanou \& Vafeas, 2005).

Governance practices restrict the managers' capacity to manipulate earnings (K. Y. Chen, Elder, \& Hsieh, 2007; Huang, Mishra, \& Raghunandan, 2007; Jaggi, Leung, \& Gul, 2009; Jaggi \& Tsui, 2007; Kim \& Yi, 2006; Peasnell, Pope, \& Young, 2005). Singh et al. (2016) Quantified corporate governance by its various attributes, such as the size of the board, the board meetings frequency, the independence of the board, the duality of positions (CEO / chair), the rate of audit committee meetings and the independence of the audit committee. Earnings management has been documented differently by extant literary works, particularly on the role of the audit committees' effectiveness in constraining such opportunistic behavior of the management. An audit committee is assigned with the responsibility of ensuring quality financial reporting in the firm, prompting an investigation into its role in curbing earnings management in the firms. The next section of the article is on the review of literature and hypothesis development, and the subsequent sections are organized into research methods, results and discussion, and finally, the conclusion.

\section{Literature Review}

\section{Agency Theory}

Agency theory argues that an agency relationship is said to exist when one party to the agency relationship (principal) gives another party (agent) a delegation to execute a job or service and assigns the authority to decide on his behalf (Jao \& Pagalung, 2011; Jensen \& Meckling, 1976). In an organizational setup, therefore, an agency relationship exists where the shareholders delegate the role of managing the firm to the agents who are the firms' management. The problem with this principle arises from the separation of owners and management rights. Agency conflicts arise if agents do not perform as required by the owners, who are the firms' shareholders. The disagreement can lead to information asymmetry, since management may not conceal information to investors in an openly and transparently. The conception of audit committees derives its motivation from the concept of agency theory, which suggests a monitoring mechanism to be put in place. Jensen and Meckling (1976), though, argue that the delegation of authority to control the firm by the Principal, as well as the resulting division of duties, is helpful in the creation of a productive and rewarding organization.

The conflict of interests according to agency theory that arise between the parties to the agency contract can be avoided or minimized by the enactment of a good corporate governance mechanism (Nasution \& Setiawan, 2007), such as the audit committee, ownership structures, the board of directors and other internal controls that would act as a monitoring mechanism. The Agency model recommends that, due to the self-interests on the side of the agents, the principals will not take the agents as their fiduciaries, but instead they will seek to resolve their problem by implementing mechanisms that work towards converging the interests of agents with theirs and towards constraining the extent of information asymmetries and opportunistic behavior (Eisenhardt, 1989; Fama \& Jensen, 1983).

\section{Audit Committee Independence and Earnings Management}

Audit Committee Independence refers to the presence of independent directors in the audit committee (Singh et al., 2016). An audit committee should work free of any internal or external influence since the oversight organ within the firm. The Sarbanes-Oxley Law and Act (2002) stresses the need for autonomy on the audit committee for a prudent oversight of financial reporting, calling on the presence of an entire Audit Committee, 
which is independent. Klein (2002) asserts the independence of the audit committee enhances committees' effectiveness in controlling and ensuring that desirable financial reporting standards are met. Extant studies also associate fewer financial misstatements with higher independence in the audit committees,(e.g. Abbott, Parker, \& Peters, 2004) which suggests that an entirely independent audit committee is preferable and is capable of protecting the interests of the owners as well efficient in performing its oversight function, especially due to its ability to assess issues critically (e.g. Abbott et al., 2004; Bédard, Chtourou, \& Courteau, 2004; Yang \& Krishnan, 2005).

As supported by Vafeas (2005) and Yang and Krishnan (2005), Non-executive individuals from the audit committee have an enthusiasm for keeping up and improving their reputation and are accordingly keen on achieving a significant level of financial reporting quality, which lessens managerial earnings manipulation. While others found a positive relationship (e.g. Beasley, Carcello, Hermanson, \& Neal, 2009; Bryan, Liu, Tiras, \& Zhuang, 2013). An impartial audit committee is widely considered to service the shareholders with an efficient oversight of both the financial reporting decisions pursued by the executives and ensure the integrity of the financial statements. Deli and Gillan (2000) argued that the AC acts as a pillaring agent that fosters the autonomy of both the internal and external auditors. Consequently, the audit committees are deemed to be much more efficient in supervising financial reporting processes, provided they are independent enough to shield them from external influence. Xie, Davidson III, and DaDalt (2003) argued that an independent audit committee would give superior governance, particularly in comparison with a less independent committee. Such assertions, recommendations, and aspirations are backed by the requirements in the Sarbanes-Oxley Act mandating publicly trading firms to have fully independent audit committees.

In contrast, some past researchers evidenced no proof of a correlation between the quantity of independent members from the audit committee and earnings management (e.g. Davidson, Goodwin-Stewart, \& Kent, 2005; He, Wright, Evans, \& Crowe, 2007; J. W. Lin, Li, \& Yang, 2006; Xie et al., 2003; Yang \& Krishnan, 2005). They propose that the time available to the external members isn't adequate to enable them to track managerial exercises associated with financial reporting.

\section{Ho: Audit committee independence has no significant effect on earnings management}

\section{Audit Committee Meeting Frequency and Earnings Management}

Most of the meetings held by the audit committees are conducted to enhance the efficiency of the management and not to exploit their own goals. Agency theory contends that audit committees give a viable oversight of the companies' board of directors with a possibility that when the AC has a higher number of meetings held annually and is more independent, then managers' tendency to manage earnings reduces. Xie et al. (2003) found out that ACs who meets more often are great administrators in directing the financial reporting processes. The number of meetings held by the audit committee is an indicator of the degree to which the committees' activity level is assessed. Its effectiveness is reflected by the ability of the members to conduct their oversight activities appropriately. The committee's activity level is very important to the extent that it cannot be fully effective in its absence, irrespective of whether or not the committee has the appropriate composition and resources in place.

Karamanou and Vafeas (2005) recommends that an audit committee which meets regularly is likely to carry out its oversight function effectively, whereas Li, Mangena, and Pike (2012) asserts that active audit committees with regular meetings in a year give its participants more chances to address and analyze the concerns presented to them about the financial reporting standards of the organization. Xie et al. (2003) state that effective monitoring is correlated with audit committees who hold more meetings within a given financial cycle. Also, Klein (2002) states that an active audit committee as determined by the meeting frequency is positively linked 
to the latter's independence, and adds that its independence affects the committee's robustness in overseeing financial reporting. Therefore, it is arguable that an audit committee with regular meetings has an upper hand in successfully identifying and deterring earnings management practices that occur more regularly.

According to Choi, Jeon, and Park (2004), active ACs are highly probable than dormant committees to uncover earnings management. However, previous studies provide inconclusive output, for instance, Xie et al. (2003) and Vafeas (2005) found out that there is a significant negative correlation between the meeting frequency and earnings management, and a positive relationship between the rate of meetings and the value of earnings, while Yang and Krishnan (2005) evidence any significant relationship. In an Australian study, Davidson et al. (2005) and Baxter and Cotter (2009) also find no significant effect of audit committee meeting frequency on earnings management. Results from further studies conducted in Singapore and Malaysia also provide mixed findings, ranging from a negative correlation (Van Der Zahn \& Tower, 2004; Yusof, 2009) to no relation (Abdul Rahman \& Haneem Mohamed Ali, 2006) between the meeting frequency and earnings management.

\section{Ho: Audit committee meeting frequency has no significant effect on earnings management}

\section{Audit Committee Financial Expertise and Earnings Management}

It is widely accepted that the audit committee's central role is often to evaluate the mechanism of financial reporting and achieve the best standards of financial statements. Therefore, the presence of the audit committee's accounting and financial skills will improve its productivity and capacity to identify and avoid earnings management. Specialized experience in auditing and accounting (financial expertise) therefore, is advantageous to the audit committee members in conducting an objective and meaningful analysis of accounting concerns given to them (Baxter \& Cotter, 2009), examine different accounting procedures and figures, and in tackling the projections and expectations relating to accounting, in the implementation of new accounting policies (Beasley et al., 2009). The Sarbanes-Oxley Law and Act (2002) stipulates that a minimum of one member in the audit committee should be a financial expert, but to more advantage, if many members are financial experts in the AC.

Expertise in finance helps the audit committee representatives to recognize and raise intelligent concerns that task managers and external auditors for the realization of a greater degree of financial reporting (Bédard \& Gendron, 2010). Additionally, S. Chen and Komal (2018) states that the financial experience of the AC has a positive and greater association with the quality of the earnings than does non-accounting financial experts. The literature demonstrates that the effectiveness of the AC is improved by the participation of a higher proportion of financial experts in the committee (Dhaliwal, Naiker, \& Navissi, 2010; Naiker \& Sharma, 2009). Xie et al. (2003) contended that companies wherein the ACs have financially experienced participants evidence lower earnings management.

Many U.S. based researchers found that higher financial expertise of audit committee members is characterized by reduced earnings management (e.g. Bédard et al., 2004; Bryan et al., 2013; Dhaliwal et al., 2010; Keune \& Johnstone, 2012; Krishnan, Wen, \& Zhao, 2011). According to Xie et al. (2003), there is a positive impact of expertise on the earnings quality, while using the quality of the earnings forecast as a quality measure. Karamanou and Vafeas (2005) indicate that financial expertise has a significant effect on the quality of reported earnings by also using earnings estimates as an indicator. Elsewhere, Choi et al. (2004) found out that there is lower earnings management if the audit committee has enough representation of the financial experts. The same output is evidence in the study of Woidtke and Yeh (2013) while using data from three East Asian countries and (Sharma, Sharma, \& Ananthanarayanan, 2011) for New Zealand. In a study conducted in Germany, by Velte and Stiglbauer (2011), for situations in which more than 50 percent of the AC members are professionals, financial experience results in fewer earnings manipulation. 
However, a few studies have indicated an insignificant effect of financial knowledge on earnings management (e.g. Ghosh, Marra, \& Moon, 2010; Jamil \& Nelson, 2011; Rainsbury, Bradbury, \& Cahan, 2008; Song \& Windram, 2004).

\section{Ho: Audit committee financial expertise has no significant effect on earnings management}

\section{Methods}

The research focused on publicly trading firms at the Kenyan Nairobi Securities Exchange. Kenya suited the research context as it hosts one of the fastest-growing securities exchanges operating in an emerging market. The target population for the 65 firms listed at the NSE, while the data was obtained from the audited financial reports of firms that operated consistently for thirteen consecutive years between 2004 and 2017. The study adopted an explanatory research design and a panel approach towards arriving at the study's conclusions. A total of 35 listed firms participated in the study resulting in a total of 490 firm-year observations.

Earnings management was measured using discretionary accruals primarily as suggested by the modified jones model developed by Dechow, Sloan, and Sweeney (1995). Accrual is the difference between the reported earnings and cash earnings during the period (Singh et al., 2016). According to Healy (1985), accruals are further broken down into non-discretionary and discretionary (NDA + DA), where non-discretionary accruals are the accounting adjustments made by the management on the firm's cash flows and is mandated by the accounting standard-setting bodies, while discretionary accruals refers to the cash flow changes selected by the management. Discretionary accruals were given by the residuals of the OLS regression model, where the variables were lagged by total assets to avoid heteroscedasticity problem.

$$
\frac{T A_{i t}}{A_{i t-1}}=\propto_{1} \frac{1}{A_{i t-1}}+\propto_{2} \frac{\Delta R E V_{i t}-\Delta R E C_{i t}}{A_{i t-1}}+\propto_{3} \frac{P P E_{i t}}{A_{i t-1}}+D A_{i t}
$$

Where:

$T A_{i t}$ Refers to the Total Accruals in year $\mathrm{t}$

$A_{i t-1}$ Refers to firm i's Total Assets at the end of year t-1

$\triangle R E V_{i t}$ Refers to firm i's revenues in year t less revenue in year $\mathrm{t}-1$

$\triangle R E C_{i t}$ Refers to firm i's Receivables in year t fewer receivables in year t-1.

$P P E_{i t}$ Refers to the gross property plant and equipment at the end of year $\mathrm{t}$

$\propto_{1}, \propto_{2}$ and $\propto_{3}$ are the firm-specific parameters

$\mathrm{DA}_{\mathrm{it}}$ is the Discretionary Accruals for firm i for year $\mathrm{t}$

Total accruals are the Net income less cash flow from operating activities

Audit Committee Independence (ACI) is defined as the presence of independent directors in the audit committee (Singh et al., 2016) and was measured by the total number of independent audit committee directors divided by the total number of directors participating in the audit committee (Al-dhamari, Ismail, \& Izah, 2017; Ali Shah, Butt, \& Hassan, 2009; Klein, 2002; Mohamed Yunos, Ismail, \& Smith, 2012; Singh et al., 2016).

Audit Committee Meeting Frequency (ACMF) refers to how often members meet to discuss various issues facing a firm (Katmon \& Al Farooque, 2017). This was measured as the number of audit committee meetings 
held during the year used (Al-dhamari et al., 2017; Katmon \& Al Farooque, 2017; Kolsi \& Grassa, 2017; Singh et al., 2016).

Audit Committee Financial Expertise (ACFE) refers to the financial qualification and competencies of the members. It is measured as the proportion of audit committee directors who are members of an accounting association or body to the total number of audit committee directors in line with Al-dhamari et al. (2017) and (Huang, Rose-Green, \& Lee, 2012).

The research controlled for firm size (FS), which is the natural log of total assets. The study controlled for firm size because larger companies are expected to have a more efficient oversight mechanism and risk more public scrutiny(Bédard et al., 2004; Dechow et al., 1995). Small businesses are also anticipated to be involved in earnings management to cover their higher marginal costs compared with large businesses that benefit from economies of scale (J. W. Lin, Kang, \& Roline, 2009).

Firm age (FA)is the time that a firm has been in operation, and it has an implication on its level of earnings management practices. Different managerial and firm motives motivate this. According to Lee and Masulis (2011), managers of more mature companies have fewer opportunities to generate higher earnings artificially, indicating a negative relationship between company age and earnings management. Young firms are more likely to require external financing, which may give them added motivation to manipulate earnings (Desai, Hogan, \& Wilkins, 2006). It is measured by the year of observation minus the establishment date of the company.

A Pearson moments correlation coefficients were further used to check for associations between the research variables and a multiple panel regression model to test the hypotheses at a 0.05 significance level. The overall panel regression model is specified as;

$$
E M_{i t}=\beta_{0}+\beta_{1} F S I Z_{i t}+\beta_{2} F A_{i t}+\beta_{3} A C I_{i t}+\beta_{4} A C M F_{i t}+\beta_{5} A C F E_{i t}+\varepsilon_{i t}
$$

Where:

$\begin{array}{lll}\mathrm{EM} & = & \text { Earnings Management } \\ \mathrm{ACI} & = & \text { Audit Committee of Independence } \\ A C M F & = & \text { Audit Committee Meeting Frequency } \\ A C F E & = & \text { Audit Committee Financial Expertise } \\ \mathrm{FSIZ} & = & \text { Firm Size } \\ \mathrm{FA} & = & \text { Firm Age } \\ \beta_{0 \ldots . . .} \beta_{5} & = & \text { Coefficients of the equations } \\ \varepsilon & = & \text { error term } \\ \mathrm{t} & =\text { time } \\ \mathrm{i} & =\text { Firm }\end{array}$

\section{Results}

Table 1 indicates that the total number of observations for the study was 490. The findings further show that earnings management had a mean (median) of -0.138 comparable with the findings in Puat Nelson and Devi (2013) and Albersmann and Hohenfels (2017), where they found a negative average discretionary accrual. This is an indication that the firms get involved in earnings management practices and that, on average, they practice 
income-decreasing earnings management though at minimum levels. The same findings were also evident in Hassan and Ahmed (2012) where they stated that on average, the sample firms manage accruals downwards (income-decreasing accruals) and their average value over a significant stretch ought to be close to zero (Tehranian, Cornett, Marcus, \& Saunders, 2006).

The Audit Committee Independence (ACI) had a mean of $85.3 \%$ signifying a good representation of the outside executives within the audit committee. This is comparable with the proportion evident in a study conducted by Klein (2002) on publicly-trading US firms that operate within the NYSE, where the study found out that, on average, $80 \%$ of members in the Audit Committee were independent. The higher percentage also supports the findings of Sun, Lan, and Liu (2014).

The Audit Committee Meeting Frequency (ACMF) had a mean of 4 meetings per year, similar to the findings in previous studies of Albersmann and Hohenfels (2017) and Buallay and AlDhaen (2018). This is largely due to the fact that most of the companies in the NSE stick to quarterly meetings as a policy. Buallay and AlDhaen (2018) in a study using firms listed in the Gulf Cooperation Council (GCC) realized an average of 4.38 yearly meetings and suggested that there should be at least four meetings per year conducted by the AC, while Albersmann and Hohenfels (2017) recommended between 4 to 5 meetings per year.

Firm size had a mean of 7.056, meaning firms operating at the NSE are heterogeneous in terms of size and were highly dispersed from the mean, thus suggesting the need to control for the variable in the study while firm age had a mean of 67.7 years.

\begin{tabular}{lccccc}
\multicolumn{7}{l}{ Table 1: Descriptive Statistics Results } \\
\hline Variable & Obs & Mean & Std. Dev. & Min & Max \\
\hline EM & 490.000 & -0.138 & 0.842 & -3.401 & 1.997 \\
ACI & 490.000 & 0.853 & 0.234 & 0.100 & 1.000 \\
ACMF & 490.000 & 4.080 & 2.283 & 1.000 & 15.000 \\
ACFE & 490.000 & 0.336 & 0.179 & 0.100 & 1.000 \\
FS & 490.000 & 7.056 & 0.713 & 4.806 & 8.747 \\
FA & 490.000 & 67.700 & 27.505 & 18.000 & 148.000 \\
\hline
\end{tabular}

Table 2 indicates that audit committee independence (ACI) has a negative and significant $(\mathrm{r}=-0.285, \mathrm{p}<0.01)$ association with earnings management. This output concurs with that realized in the previous studies of Elijah and Ayemere (2015) and Latif and Abdullah (2015), where they found out that more independence in the AC reduces earnings management. The audit committee meeting frequency (ACMF) has a negative and significant $(\mathrm{r}=-0.448, \mathrm{p}<0.01)$, indicating that as the number of meetings held annually by the audit committee increases, earnings management significantly decreases. This agrees with the findings of Katmon and Al Farooque (2017) and Albersmann and Hohenfels (2017), where they also realized a negative relationship between the number of meetings conducted by the AC and earnings management.

Audit committee financial expertise (ACFE) indicated a negative and significant $(r=-0.619, p<0.01)$ association with earnings management. The results are comparable with those realized in the previous studies (e.g. Albersmann \& Hohenfels, 2017; Katmon \& Al Farooque, 2017; Puat Nelson \& Devi, 2013; Vafeas, 2005), where they found out that the larger the proportion of financial expertise in the audit committee, the lesser is earnings management. Firm size showed a positive and significant $(r=0.123, p<0.01)$ association with earnings management. This is interpreted to mean that large firms are more likely to engage in earnings management practices as compared to small firms. These findings were also evident in the previous study of Puat Nelson and Devi (2013). The output also indicated that firm age is positively and significantly $(\mathrm{r}=0.219, \mathrm{p}<0.01)$ correlated with earnings management. 
Table 2: Correlation Results

\begin{tabular}{lcccccr}
\hline & EM & ACI & ACMF & ACFE & FS & FA \\
\hline EM & 1 & & & & & \\
ACI & -0.285 & 1 & & & & \\
ACMF & -0.448 & 0.099 & 1 & & & \\
ACFE & -0.619 & 0.069 & 0.507 & 1 & 1 & \\
FS & 0.123 & 0.157 & 0.118 & 0.016 & -0.176 & 1 \\
FA & 0.219 & -0.195 & -0.036 & -0.110 & \\
\hline
\end{tabular}

The regression results in Table 3 shows that Audit Committee Independence (ACI) has a negative and significant effect $(\beta=-0.813, \varrho<0.05)$ on earnings management. The independence of the audit committee has a significant effect on earnings management. The audit committee acts as a corporate governance mechanism on matters concerning financial reporting. Its independence from the influence of management depends on the ratio of the outside directors who bring in an independent oversight role within the firm. It follows, therefore that, a higher proportion of outside directors in the audit committee provides more independent monitoring, thus the observed reduction managerial manipulation of reported earnings. The results concur with the findings in previous studies (e.g. Hassan \& Ahmed, 2012; Klein, 2002; Latif \& Abdullah, 2015; Mohd Saleh, Mohd Iskandar, \& Mohid Rahmat, 2007; Tehranian et al., 2006), where they found out that the independence of the audit committee reduces earnings management in a firm.

Audit Committee Meeting Frequency (ACMF) has a negative and significant effect $(\beta=-0.028, \varrho<0.05)$ on earnings management. The number of meetings held by the audit committee in a year significantly affects managerial engagement in earnings management. An increase in the frequency of meetings held by the AC means a higher level of activeness of the AC, thus limiting the management from manipulating earnings to suit their desires. However, for efficiency and effectiveness purposes, the meetings should not be too many to magnify the agency costs of monitoring and create a conflict of interest, respectively, since the members' interests in attending the meetings will be diverted from that of the firm. In contend, Albersmann and Hohenfels (2017) suggested 4 to 5 meetings per year as enough frequency to reduce earnings management. Xie et al. (2003) find that an AC that meets regularly becomes better supervisors in overseeing the financial reporting process. Equally, other studies such as Vafeas (2005) and Cornett et al. (2009) also found out that more meetings reduce earnings management.

Audit Committee Financial Expertise (ACFE) has a negative and significant effect $(\beta=-2.064, \varrho<0.05)$ on earnings management. The financial expertise of the audit committee has a significant effect on earnings management. A higher proportion of members in the $\mathrm{AC}$ with financial expertise provide the necessary monitoring mechanism to assess and evaluate the financial reports towards detecting manipulated earnings. This, therefore, reduces opportunistic earnings management within the firms. Abdul Rahman and Haneem Mohamed Ali (2006) stated that the financial expertise of the audit committee members is associated with lower levels of earnings management. Additionally, Vafeas (2005) and Puat Nelson and Devi (2013) also documented that a greater proportion of financial expertise deters earnings management practices.

The control variable Firm size (FS) had a positive and significant $(\beta=0.171 ; p=0 . \varrho<0.05)$ effect on earnings management. Large firms manage earnings more as compared to small firms. This is because the management of large firms is under intense pressure to produce impressive results. The management, therefore, will manage earnings upwards or downwards to suit their targets. These findings concur with those found in Klein (2002), Xie et al. (2003), Puat Nelson and Devi (2013), and (San Martín Reyna, 2018), who found out that firm size has a positive and significant effect on earnings management. 
Firm Age (FA) has a positive and significant $(\beta=0.006, \varrho<0.05)$ effect on earnings management. Older firms engage in more earnings management compared to young firms. The firms' life cycle justifies the fact that they perform well during early stages and experience continued growth, until the declining and maturity phase where they are older enough to start experiencing declining performance, managers under pressure to register continued growth in performance are compelled to engage in earnings manipulation to maintain a good false image of the firm.

\section{Table 3: Regression Results}

\begin{tabular}{|c|c|c|c|c|c|c|}
\hline \multicolumn{5}{|c|}{ Random-effects GLS regression } & \multicolumn{2}{|r|}{ Number of obs $=490$} \\
\hline \multicolumn{5}{|c|}{ Group variable: firmid } & \multicolumn{2}{|c|}{ Number of groups $=35$} \\
\hline \multicolumn{6}{|c|}{ R-sq: within $=0.5806$} & \\
\hline \multicolumn{5}{|c|}{ between $=0.3956$} & & \\
\hline \multicolumn{6}{|c|}{ overall $=0.4983$} & $\begin{array}{l}\operatorname{avg}=14 \\
\max =14\end{array}$ \\
\hline \multirow{2}{*}{\multicolumn{5}{|c|}{$\operatorname{corr}\left(\mathrm{u} \_\mathrm{i}, \mathrm{X}\right)=0$ (assumed) }} & \multirow{2}{*}{\multicolumn{2}{|c|}{$\begin{array}{l}\text { Wald chi } 2(2)=644.94 \\
\text { Prob }>\text { chi } 2=0.000\end{array}$}} \\
\hline & & & & & & \\
\hline EM & Coef. & Std.Err. & z & $\mathrm{P}>_{\mathrm{Z}}$ & \multicolumn{2}{|c|}{ [95\% Conf. Interval } \\
\hline ACI & -0.664 & 0.114 & -5.810 & 0.000 & -0.889 & -0.440 \\
\hline ACMF & -0.095 & 0.011 & -8.300 & 0.000 & -0.118 & -0.072 \\
\hline ACFE & -2.275 & 0.153 & -14.860 & 0.000 & -2.575 & -1.975 \\
\hline FS & 0.111 & 0.054 & 2.060 & 0.040 & 0.005 & 0.217 \\
\hline FA & 0.004 & 0.002 & 1.560 & 0.118 & -0.000 & 0.009 \\
\hline _cons & 0.541 & 0.416 & 1.300 & 0.193 & -0.274 & 1.356 \\
\hline sigma_u & 0.426 & & & & & \\
\hline sigma_e & 0.424 & & & & & \\
\hline rho & 0.502 & (fracti & of varian & e due to & u_i) & \\
\hline
\end{tabular}

\section{Discussion}

An effective audit committee proves to reduce managerial discretional accruals management. More independence, more meeting frequency (activity), and higher financial expertise increase the AC effectiveness. The audit committee's independence is an effective corporate governance mechanism that aids in constraining earnings management in a firm. A higher proportion of independent members in the audit committee is preferable as an effective monitoring mechanism on matters about financial reporting. The higher the number of meetings held in a year by the audit committee means a decrease in earnings management. A higher frequency of the audit committee meetings signifies a higher level of activeness in detecting earnings management in a firm as compared to a dormant committee. A higher proportion of members with financial expertise translate to lesser earnings management in a firm. Financial experts in the audit committee heighten the propensity of the committees' ability to assess and evaluate objectively the financial reports and accounting issues presented to them since they are knowledgeable of the various accounting methods that require managerial discretion in reporting.

As a means towards reducing earnings management, a higher and clear proportion of independent members in the audit committee is preferable for an independent oversight role. The audit committee meeting frequency is an important aspect of the level of activity in the audit committee. Firms should, therefore, put more emphasis on the meetings held by the audit committee as a means of ensuring active monitoring of financial reporting in the firm. There is a need to boost the representation of members with financial expertise in the audit committee to achieve quality financial reporting with low levels of earnings management.

Funding: This research received no external funding 
Acknowledgments: We acknowledge the administrative and technical support from the school of business and economics, Moi University

Conflicts of Interest: The authors declare no conflicts of interest

\section{References}

Abbott, L. J., Parker, S., \& Peters, G. F. (2004). Audit committee characteristics and restatements. Auditing: A Journal of Practice \& Theory, 23(1), 69-87.

Abdul Rahman, R., \& Haneem Mohamed Ali, F. (2006). Board, audit committee, culture and earnings management: Malaysian evidence. Managerial Auditing Journal, 21(7), 783-804.

Al-dhamari, R., Ismail, K., \& Izah, K. N. (2017). Governance structure, ownership structure and earnings predictability: Malaysian evidence. Al-Dhamari, RA, \& Ismail, KNIK (2013). Governance structure, ownership structure and earnings predictability: Malaysian evidence. Asian Academy of Management Journal of Accounting and Finance, 9(1), 1-23.

Albersmann, B. T., \& Hohenfels, D. (2017). Audit committees and earnings management-Evidence from the German two-tier board system. Schmalenbach Business Review, 18(2), 147-178.

Albu, C. N., \& Girbina, M. M. (2015). Compliance with corporate governance codes in emerging economies. How do Romanian listed companies “comply-or-explain”? Corporate Governance, 15(1), 85-107.

Ali Shah, S. Z., Butt, S. A., \& Hassan, A. (2009). Corporate governance and earnings management an empirical evidence form Pakistani listed companies. European Journal of Scientific Research, 26(4), 624-638.

Baxter, P., \& Cotter, J. (2009). Audit committees and earnings quality. Accounting \& Finance, 49(2), 267-290.

Beasley, M. S., Carcello, J. V., Hermanson, D. R., \& Neal, T. L. (2009). The audit committee oversight process. Contemporary Accounting Research, 26(1), 65-122.

Bédard, J., Chtourou, S. M., \& Courteau, L. (2004). The effect of audit committee expertise, independence, and activity on aggressive earnings management. Auditing: A Journal of Practice \& Theory, 23(2), 13-35.

Bédard, J., \& Gendron, Y. (2010). Strengthening the financial reporting system: Can audit committees deliver? International journal of auditing, 14(2), 174-210.

Bryan, D., Liu, M. C., Tiras, S. L., \& Zhuang, Z. (2013). Optimal versus suboptimal choices of accounting expertise on audit committees and earnings quality. Review of Accounting Studies, 18(4), 1123-1158.

Buallay, A. M., \& AlDhaen, E. S. (2018). The relationship between audit committee characteristics and the level of sustainability report disclosure. Paper presented at the Conference on e-Business, e-Services and e-Society.

Chen, K. Y., Elder, R. J., \& Hsieh, Y.-M. (2007). Corporate governance and earnings management: The implications of corporate governance best-practice principles for Taiwanese listed companies. Journal of Contemporary Accounting \& Economics, 3(2), 73-105.

Chen, S., \& Komal, B. (2018). Audit committee financial expertise and earnings quality: A meta-analysis. Journal of Business Research, 84, 253-270.

Choi, J.-H., Jeon, K.-A., \& Park, J.-I. (2004). The role of audit committees in decreasing earnings management: Korean evidence. International Journal of Accounting, Auditing and Performance Evaluation, 1(1), 37-60.

Cornett, M. M., McNutt, J. J., \& Tehranian, H. (2009). Corporate governance and earnings management at large US bank holding companies. Journal of Corporate finance, 15(4), 412-430.

Davidson, R., Goodwin-Stewart, J., \& Kent, P. (2005). Internal governance structures and earnings management. Accounting \& Finance, 45(2), 241-267.

Dechow, P. M., Sloan, R. G., \& Sweeney, A. P. (1995). Detecting earnings management. Accounting review, 193225.

Desai, H., Hogan, C. E., \& Wilkins, M. S. (2006). The reputational penalty for aggressive accounting: Earnings restatements and management turnover. The Accounting Review, 81(1), 83-112. 
Dhaliwal, D., Naiker, V., \& Navissi, F. (2010). The association between accruals quality and the characteristics of accounting experts and mix of expertise on audit committees. Contemporary Accounting Research, 27(3), 787-827.

Eisenhardt, K. M. (1989). Agency theory: An assessment and review. Academy of management review, 14(1), 57-74. Elijah, A., \& Ayemere, I. L. (2015). Audit committee attributes and earnings management: Evidence from Nigeria. International Journal of Business and Social Research, 5(4), 14-23.

Fama, E. F., \& Jensen, M. C. (1983). Separation of ownership and control. The journal of law and Economics, 26(2), 301-325.

Ghosh, A., Marra, A., \& Moon, D. (2010). Corporate boards, audit committees, and earnings management: preand post-SOX evidence. Journal of Business Finance \& Accounting, 37(9-10), 1145-1176.

Hassan, S. U., \& Ahmed, A. (2012). Corporate governance, earnings management and financial performance: A case of Nigerian manufacturing firms. American International Journal of Contemporary Research, 2(7), 214226.

He, L., Wright, S., Evans, E., \& Crowe, S. (2007). Earnings management in Australia under new ASX corporate governance guidelines. Paper presented at the Accounting Association of Australia and New Zealand Conference (2007).

Healy, P. M. (1985). The effect of bonus schemes on accounting decisions. Journal of accounting and economics, 7(13), 85-107.

Healy, P. M., \& Wahlen, J. M. (1999). A review of the earnings management literature and its implications for standard setting. Accounting horizons, 13(4), 365-383.

Huang, H.-W., Mishra, S., \& Raghunandan, K. (2007). Types of nonaudit fees and financial reporting quality. Auditing: A Journal of Practice \& Theory, 26(1), 133-145.

Huang, H.-W., Rose-Green, E., \& Lee, C.-C. (2012). CEO age and financial reporting quality. Accounting horizons, 26(4), 725-740.

Jaggi, B., Leung, S., \& Gul, F. (2009). Family control, board independence and earnings management: Evidence based on Hong Kong firms. Journal of Accounting and Public Policy, 28(4), 281-300.

Jaggi, B., \& Tsui, J. (2007). Insider trading, earnings management and corporate governance: empirical evidence based on Hong Kong firms. Journal of International Financial Management \& Accounting, 18(3), 192-222.

Jamil, N. N., \& Nelson, S. P. (2011). An Investigation on the Audit Committees Effectiveness: The Case for GLCs in Malaysia. Gadjah Mada International Journal of Business, 13(3).

Jao, R., \& Pagalung, G. (2011). Corporate governance, ukuran perusahaan, dan leverage terhadap manajemen laba perusahaan manufaktur Indonesia. Jurnal akuntansi dan auditing, 8(1), 43-54.

Jensen, M. C., \& Meckling, W. H. (1976). Theory of the firm: Managerial behavior, agency costs and ownership structure. Journal of financial economics, 3(4), 305-360.

Karamanou, I., \& Vafeas, N. (2005). The association between corporate boards, audit committees, and management earnings forecasts: An empirical analysis. Journal of Accounting research, 43(3), 453-486.

Katmon, N., \& Al Farooque, O. (2017). Exploring the impact of internal corporate governance on the relation between disclosure quality and earnings management in the UK listed companies. Journal of Business Ethics, 142(2), 345-367.

Keune, M. B., \& Johnstone, K. M. (2012). Materiality judgments and the resolution of detected misstatements: The role of managers, auditors, and audit committees. The Accounting Review, 87(5), 1641-1677.

Kim, J. B., \& Yi, C. H. (2006). Ownership structure, business group affiliation, listing status, and earnings management: Evidence from Korea. Contemporary Accounting Research, 23(2), 427-464.

Klein, A. (2002). Audit committee, board of director characteristics, and earnings management. Journal of accounting and economics, 33(3), 375-400. 
Kolsi, M. C., \& Grassa, R. (2017). Did corporate governance mechanisms affect earnings management? Further evidence from GCC Islamic banks. International Journal of Islamic and Middle Eastern Finance and Management, 10(1), 2-23.

Krishnan, J., Wen, Y., \& Zhao, W. (2011). Legal expertise on corporate audit committees and financial reporting quality. The Accounting Review, 86(6), 2099-2130.

Latif, A. S., \& Abdullah, F. (2015). The effectiveness of corporate governance in constraining earnings management in Pakistan.

Law, P., \& Act, A. (2002). Be it enacted by the Senate and House of Representatives of the United States of America in Congress assembled, Sarbanes-Oxley Act of 2002. Public Law, 107, 204.

Lee, G., \& Masulis, R. W. (2011). Do more reputable financial institutions reduce earnings management by IPO issuers? Journal of Corporate finance, 17(4), 982-1000.

Li, J., Mangena, M., \& Pike, R. (2012). The effect of audit committee characteristics on intellectual capital disclosure. The British Accounting Review, 44(2), 98-110.

Lin, J. W., Kang, G., \& Roline, A. (2009). The effects of the Blue Ribbon Committee and the Sarbanes Oxley Act of 2002 on the characteristics of the audit committees and the board of directors. Advances in Accounting, Finance \& Economics, 2(1).

Lin, J. W., Li, J. F., \& Yang, J. S. (2006). The effect of audit committee performance on earnings quality. Managerial Auditing Journal, 21(9), 921-933.

Lin, Z., Liu, M., \& Noronha, C. (2016). The impact of corporate governance on informative earnings management in the Chinese market. Abacus, 52(3), 568-609.

Mohamed Yunos, R., Ismail, Z., \& Smith, M. (2012). Ethnicity and accounting conservatism: Malaysian evidence. Asian Review of Accounting, 20(1), 34-57.

Mohammady, A. (2010). Earnings quality constructs and measures. Available at SSRN 1678461.

Mohd Saleh, N., Mohd Iskandar, T., \& Mohid Rahmat, M. (2007). Audit committee characteristics and earnings management: Evidence from Malaysia. Asian Review of Accounting, 15(2), 147-163.

Naiker, V., \& Sharma, D. S. (2009). Former audit partners on the audit committee and internal control deficiencies. The Accounting Review, 84(2), 559-587.

Nasution, M., \& Setiawan, D. (2007). Pengaruh corporate governance terhadap manajemen laba di industri perbankan Indonesia. Simposium Nasional Akuntansi X, 1(1), 1-26.

NAZIR, M. S., \& AFZA, T. (2018). IMPACT OF CORPORATE GOVERNANCE ON DISCRETIONARY EARNINGS MANAGEMENT A CASE OF PAKISTANI FIRMS. Pakistan Economic and Social Review, 56(1), 157-184.

Peasnell, K. V., Pope, P. F., \& Young, S. (2005). Board monitoring and earnings management: do outside directors influence abnormal accruals? Journal of Business Finance \& Accounting, 32(7-8), 1311-1346.

Puat Nelson, S., \& Devi, S. (2013). Audit committee experts and earnings quality. Corporate Governance: The international journal of business in society, 13(4), 335-351.

Rainsbury, E. A., Bradbury, M. E., \& Cahan, S. F. (2008). Firm characteristics and audit committees complying with'best practice 'membership guidelines. Accounting and Business Research, 38(5), 393-408.

San Martín Reyna, J. M. (2018). The effect of ownership composition on earnings management: evidence for the Mexican stock exchange. Journal of Economics, Finance and Administrative Science, 23(46), 289-305.

Sharma, V. D., Sharma, D. S., \& Ananthanarayanan, U. (2011). Client importance and earnings management: The moderating role of audit committees. Auditing: A Journal of Practice \& Theory, 30(3), 125-156.

Singh, A. K., Aggarwal, A., \& Anand, A. K. (2016). The Impact of Corporate Governance Mechanisms on Earnings Management: A Case of Indian Stock Exchange Listed Companies. Asia-Pacific Journal of Management Research and Innovation, 12(3-4), 304-316.

Song, J., \& Windram, B. (2004). Benchmarking audit committee effectiveness in financial reporting. International journal of auditing, 8(3), 195-205. 
Sun, J., Lan, G., \& Liu, G. (2014). Independent audit committee characteristics and real earnings management. Managerial Auditing Journal, 29(2), 153-172.

Tehranian, H., Cornett, M. M., Marcus, A. J., \& Saunders, A. (2006). Earnings management, corporate governance, and true financial performance. Corporate Governance, and True Financial Performance January 2006).

Vafeas, N. (2005). Audit committees, boards, and the quality of reported earnings. Contemporary Accounting Research, 22(4), 1093-1122.

Van Der Zahn, J. W. M., \& Tower, G. (2004). Audit committee features and earnings management: further evidence from Singapore. International Journal of Business Governance and Ethics, 1(2-3), 233-258.

Velte, P., \& Stiglbauer, M. (2011). Impact of audit committees with independent financial experts on accounting quality. An empirical analysis of the German capital market. Problems and Perspectives in Management, 9(4), $17-33$.

Woidtke, T., \& Yeh, Y.-H. (2013). The role of the audit committee and the informativeness of accounting earnings in East Asia. Pacific-Basin Finance Journal, 23, 1-24.

Xie, B., Davidson III, W. N., \& DaDalt, P. J. (2003). Earnings management and corporate governance: the role of the board and the audit committee. Journal of Corporate finance, 9(3), 295-316.

Yang, J. S., \& Krishnan, J. (2005). Audit committees and quarterly earnings management. International journal of auditing, 9(3), 201-219.

Yusof, M. (2009). Does audit committee constraint discretionary accruals in MESDAQ listed companies? Does Audit Committee Constraint Discretionary Accruals in MESDAQ Listed Companies. 